\title{
An Empirical Investigation of the Causal Relationship among Monetary Variables and Equity Market Returns
}

\author{
Arshad Hasan* and M. Tariq Javed
}

\begin{abstract}
This study explores the long-term dynamic relationship between equity prices and monetary variables for the period June 1998 to June 2008. Monetary variables include money supply, treasury bill rates, foreign exchange rates, and the consumer price index. The data have been examined using multivariate cointegration analysis and Granger causality analysis. Johansen and Juselius' multivariate cointegration analysis indicates the presence of a long-term dynamic relationship between the equity market and monetary variables. Unidirectional Granger causality is found between monetary variables and the equity market. In the case of money supply, a positive relationship supports the liquidity hypothesis. Impulse response analysis indicates that the interest rate shock has a negative impact on equity returns in the Pakistani equity market. Exchange rates also have a negative impact on equity returns in the short run. However inflation has little impact on returns in the equity market. Variance decomposition analysis suggests that the interest rate, exchange rate, and money supply shocks are a substantial source of volatility for equity returns. The contribution of a monetary shock to the equity returns ranges from $4 \%$ to $16 \%$ over different time lags. Similarly, the VECM also confirms the presence of a short-term relationship between monetary variables and equity returns. This state of affairs demands that monetary variables be considered an important factor in determining stock market movements. Policymakers should be more vigilant and careful in designing monetary policies as it has a direct impact on cash inflows into the capital market and on the stability of the capital market.
\end{abstract}

JEL Classification: E31, G12.

Keywords: Monetary variables, equity, causality, Pakistan.

\footnotetext{
* Muhammad Ali Jinnah University, Islamabad, Pakistan.

** Quaid-e-Azam University, Islamabad, Pakistan.
} 


\section{Introduction}

The causal relationship between monetary variables and equity returns has been one of the most debated topics in finance during the last few decades. Equity prices are the most closely observed asset prices in an economy and are considered the most sensitive to economic conditions; high volatility or abnormal movements in equity prices from fundamental values can have adverse implications for the economy. Thus, it becomes imperative to understand the relationship and dynamics of monetary variables and equity market returns.

A number of studies have been conducted to investigate the potential response of equity prices to a change in monetary variables. Jaffe and Mandelker (1976) Fama and Schwert (1977), Nelson (1976) Chan, Chen and Hsieh (1985), Chen, Roll and Ross (1986), Burnmeister and Wall (1986), Burmeister and MacElroy (1988), Chang and Pinegar (1990), Defina (1991) Kryzanowski and Zhang (1992), Chen and Jordan (1993), Sauer (1994), and Rahman, Coggin and Lee (1998) explore the relationship between inflation and equity prices. Kryzanowski and Zhang (1992), Sauer (1994), and Mukherjee and Naka (1995) explore the relationship between the foreign exchange rate and equity market returns. Burmeister and MacElroy (1988) study the relationship between short-term interest rates and equity market returns. Studies that explore the relationship between money supply and equity market returns include Friedman and Schwartz (1963), Hamburger and Kochin (1972) and Kraft and Kraft (1977) Beenstock and Chan (1988), Nozar and Taylor (1988), Sauer (1994), and Mukherjee and Naka (1995).

Financial liberalization and globalization provide further impetus for exploration of the subject, especially in the context of emerging markets such as Pakistan. This interrelationship has an economic rationale as discounted cash flow techniques for asset pricing assume that stock prices reflect expectations about futures cash flows. These expectations about cash flows are based on the expected performance of the corporate sector; the performance of the corporate sector is influenced by changing patterns in monetary variables. Therefore, any innovation in monetary variables will affect corporate profits and will ultimately reflect asset prices. If an asset pricing mechanism is efficient and reflects precisely the fundamentals of the corporate sector, then equity prices can serve as a leading indicator of future dimensions of economic activity. The efficient market hypothesis also provides that prices instantly adjust to the arrival of new information and the current prices of securities reflect all the information available about the security. Thus asset prices generally react sensitively to the arrival of new information. This response is neither equal nor homogeneous across all economic changes, and it becomes imperative to investigate the interactions among monetary factors 
and equity prices since it will provide the foundations for the formulation of monetary policy in the country.

The influence of monetary variables on equity returns has attracted considerable attention in both developed and developing countries. Many studies have been conducted to find the long-term equilibrium relationship between stock returns and monetary variables for the USA, Japan, and other industrially developed countries. This study focuses on Pakistan as a rapidly growing market in South Asia. The Pakistani equity market has shown tremendous growth in the last few years: The KSE-100 index rose from 1,773 index points in January 2000 to 15,125 in March 2008. This phenomenal growth has also attracted foreign investors and portfolio investment has increased four-fold. In the current economic scenario, it is necessary to explore the relationship between monetary variables and equity returns so that the current dynamics of monetary policy can be examined.

This study examines the long-run dynamic relationship between equity prices and four monetary factors, including the money supply, treasury bill rates, foreign exchange rates, and inflation rates for the period June 1998 to June 2008, using a multivariate cointegration analysis. We also explore the short-term dynamics of equity prices using the VECM. These variables are important as prior studies provide evidence that they have a significant relationship with equity prices in several developed and emerging markets. The study also investigates how the equity market responds to innovations in monetary variables by using an impulse response function and variance decomposition analysis.

The study will help understand the dynamics of equity market activities in an emerging market by identifying monetary variables that affect the equity market, and quantifying the impact of changes in monetary variables on equity market movements. This will enable investors and portfolio managers to make effective investment decisions. It will also facilitate policymakers in the formulation of policies that will not only encourage more capital inflows into the capital market but also provide it with stability.

The paper is arranged in four sections. Section II briefly surveys the empirical literature on the relationship among macroeconomic variables and capital markets. Section III explains the methodology adopted and data employed. The empirical results are discussed in Section IV and Section V concludes the paper. 


\section{Literature Review}

The efficient market hypothesis provides that asset prices respond to the arrival of new information. This response is stronger in the case of certain economic events whereas in other cases it may be weaker. Empirical studies try to identify factors that have a significant influence on equity prices: monetary factors are no exception.

The relationship between equity market returns and exchange rates has attracted the attention of academics and researchers during the last decade due to significant changes in the financial world. This period is known for the emergence of new capital markets, elimination of barriers to capital flows and foreign exchange restrictions, and the adoption of flexible exchange rate arrangements in emerging and transition countries. While these attributes have opened the door for investment opportunities, they have simultaneously increased the volatility of exchange rates and contributed significantly to the overall risk associated with investment decisions and portfolio diversification. Interaction between foreign exchange and equity markets is now more complex and needs greater attention. It is worth mentioning that no consensus exists among academics regarding the presence of a relationship between stock prices and exchange rates, and the direction of the relationship.

Bahmani and Sohrabian (1992) examine the relationship between the exchange rate and equity market returns for the period 1963-1988 by employing cointegration analysis and Granger causality analysis. The study provides evidence of bidirectional causality in the short run. Yu (1997) finds a bidirectional relationship between exchange rates and the equity market in Japan and unidirectional causality flowing from changes in exchange rates to changes in stock prices in Hong Kong. However no causality has been observed in the daily time series of the Singapore market during 1983-1994. Abdalla and Murinde (1997) also examine the relationship between the exchange rate and equity prices in India, Pakistan, Korea and the Philippines for the period 1985-1994 by employing cointegration analysis. The results do not provide evidence of a causal relationship in Korea and Pakistan, but do so of unidirectional causality between the exchange rate and equity prices in India and the Philippines. In India, causality flows from exchange rates to equity prices while in the Philippines, unidirectional causality runs from the equity market to the exchange rate.

Muhammad and Rasheed (2003) explore the relationship between exchange rates and equity prices in Pakistan, India, Sri Lanka, and Bangladesh for the period 1994-2000. The results indicate that no 
relationship exists between equity markets and foreign exchange rates in the long or short run in India and Pakistan. However, bidirectional causality is observed between exchange rates and equity markets in Bangladesh and Sri Lanka. Stavárek (2005) examines the presence of causal relationships between equity prices and effective exchange rates in Austria, France, Germany, the UK, Czech Republic, Hungary, Poland, Slovakia, and United States for the period 1970-2003. Results provide evidence of unidirectional causality in the long run as well as short run. Results also indicate that this causal relationship is stronger in developed markets, i.e., Austria, France, Germany, the UK, and US. Moreover, the relationship is found stronger for the period 1993-2003 than 1970-92.

Academics as well as professional observers have explored the relationship between stock prices and various monetary variables that are subjective to monetary policy. One such variable is money supply; initial studies conducted in the 1960s and 1970s generally indicated a strong leading relationship between money supply changes and equity prices. However, subsequent studies have raised questions about the nature of this relationship. They have confirmed the presence of a relationship between money supply and stock prices but the timing of the relationship remains debatable. Rozzef (1974) examines stock market efficiency with respect to money supply by employing regression analysis and trading rule analysis and finds that equity market returns do not lag behind money supply. The study confirms EMH and provides that current equity returns incorporate all information about historical as well as anticipated future changes in money supply. Beenstock and Chan (1988) examine the relationship between equity markets and a set of macroeconomic variables and provide evidence of a positive relationship between equity returns and money supply and inflation.

The relationship between inflation, interest rates, and equity prices is not direct and consistent. Equity prices are based on two factors: (i) discount rate and (ii) expected cash flows. Interest rates and inflation affect both. Different possibilities may exist with respect to expected equity prices. Equity prices may be stable when an increase in interest rates is the result of an increase in the rate of inflation and firms are able to increase prices in line with cost increases. In such a situation, equity prices might not experience a significant change as the negative effect of an increased discount rate is offset by the increase in corporate earnings. However, equity prices may show some negative trend when firms are not able to increase prices proportionately in response to higher costs. However, the impact is most negative when the required rate of return increases and expected cash flows decrease due to inflation. The effect of interest rate changes on stock prices will depend on what caused the change in interest rates and the effect of this event on 
expected cash flows on common stock. We cannot be certain whether this change in cash flows will augment or offset the change in interest rates. However, earlier studies like Nelson (1976), Mandelker (1976), Fama and Schwert (1977), and Chen, Roll and Ross (1986) provide evidence of a negative relationship between inflation and equity prices. The latter examines the presence of a long-run relationship between equity prices and seven macroeconomic variables for the US, which include monetary as well as real sector variables. Monetary variables include inflation and interest rates. The results provide evidence, during periods of a high volatility yield curve that unanticipated inflation can explain expected returns.

Hamao (1988) uses the methodology proposed by Chen, Roll and Ross (1986) for the Japanese economy and reveals that variations in expected inflation and unexpected variations in the risk premium and the term structure of interest rates influence equity returns significantly. However, variations in macroeconomic activities are found to be weakly priced in Japan in comparison with variations priced in the US.

Mukherjee and Naka (1995) explore the long-term relation between equity prices in the Japanese stock market and six macroeconomic variables, i.e., money supply, industrial production, exchange rate, inflation, long term government bond rates, and the call money rate by employing monthly data for the period $1 / 71$ to $12 / 90$. They employ a vector error correction model (VECM) to investigate the relationship among these variables and provide evidence of a positive relationship between equity prices and money supply, exchange rate, and industrial production. However, the study is mixed with reference to interest rates and inflation. Zhao (1999) explores the possibility of long-run relationships among industrial production, inflation, and equity prices in the Chinese capital market by employing monthly data for the period $1 / 1993$ to $3 / 1998$. The study reveals a significant negative relationship between equity prices and inflation, and also shows that industrial production significantly influences equity prices in the Chinese economy while the direction of this relationship is negative.

Nishat and Rozina (2001) analyze causal relationships between the Karachi Stock Exchange Index and inflation, industrial production, narrow money, and the money market rate by employing a vector error correction model for the period 1/1973 to12/2004. Results indicate the presence of two cointegrating equations among macroeconomic variables. Industrial production and inflation are identified as the largest determinants of equity prices in the Karachi Stock Exchange. Industrial production has a positive relationship with equity prices whereas inflation is negatively associated with 
stock prices. Granger causality is found flowing from macroeconomic variables to stock price, as is industrial production.

Maysami and Koh (2000) examine long-term dynamic interactions between the Strait Times Index (STI) and macroeconomic variables for the period 1988 to 1995 by employing a vector error correction model (VECM). The variables are seasonally adjusted money supply, industrial production index, foreign exchange rate, retail price index (inflation), domestic exports, and interest rates. Results indicate a cointegrating vector among returns on the Strait Times Index (STI) and money supply growth, inflation, term structure of interest rates, and changes in exchange rates. This study investigates the long-term dynamic relationship among S\&P 500, Nikkei 225 and STI by using cointegration analysis and finds that the equity markets of the US, Japan and Singapore are co-integrated.

Hussain and Mahmood (2001) investigate the long-run causal relationship between equity prices and macroeconomic variables for the period $7 / 1959$ to $6 / 1999$ by employing a vector error correction framework. Annual data for gross domestic product, consumption and investment is analyzed and it is concluded that a long-run relationship exists between equity prices and macroeconomic variables. Results also reveal the presence of unidirectional causality flowing from macro variables to stock prices. However, the equity market is not found to influence aggregate demand so its movement cannot be termed as a leading indicator of economic activity.

Mishra (2004) investigates the long-run dynamic causal relationship between equity market and macroeconomic variables in India including the foreign exchange rate, interest rate and demand for money for the period 1992 to 2002 by employing the vector auto regression (VAR) technique. This paper applies the Granger causality test to monthly data to examine the direction of the relationship and finds evidence of unidirectional causality flowing from the foreign exchange rate to the interest rate and demand for money. However, no Granger causality is found between equity returns and exchange rate returns.

Akmal (2007) investigates the relationship between equity market prices and inflation in Pakistan for the period 1971-2006 by employing the autoregressive distributed lag (ARDL) approach to observe cointegration among variables and provides evidence that equity returns are hedged against inflation in the long run. 


\section{Data Description and Methodology}

We investigate the long-term dynamic interaction between the Pakistani equity market and monetary variables by employing monthly data for the period $6 / 1998$ to $6 / 2008$. The monetary variables we use include money supply, consumer price index, interest rate and exchange rate. The preference for monthly data is in line with earlier work done by Chan and Faff (1998) to explore the long-run relationship between macroeconomic variables and capital markets.

\section{Stock Market Returns}

Stock market returns have been calculated by using following equation

$$
\mathrm{R}_{\mathrm{t}}=\ln \left(\mathrm{P}_{\mathrm{t}} / \mathrm{P}_{\mathrm{t}-1}\right)
$$

Where $R_{t}$ is return for month ' $t$ '; and $P_{t}$ and $P_{t-1}$ are closing values of KSE- 100 Index for month ' $t$ ' and ' $t-1$ ' respectively.

\section{Money Growth Rate}

Narrow money $\left(\mathrm{M}_{1}\right)$ is used as a proxy for money supply. The money growth rate has been calculated by using the log difference for narrow money $\left(\mathrm{M}_{1}\right)$

$$
\text { Money Growth Rate }=\ln \left(\mathrm{M}_{\mathrm{t}} / \mathrm{M}_{\mathrm{t}-1}\right)
$$

\section{Change in Interest Rate}

Treasury bill rates are used as a proxy for the interest rate. Change is measured by $\log$ difference to $\mathrm{T}$ bill rates.

Change in the Interest Rate $=\ln \left(\mathrm{TB}_{\mathrm{t}} / \mathrm{TB}_{\mathrm{t}-1}\right)$

\section{Change in Foreign Exchange Rate}

The change in the foreign exchange rate is measured by employing the end-of-month US $\$ /$ Rs exchange rate and the change in value is worked out through $\log$ differencing, i.e.,

$$
\text { Change in Foreign Exchange Rate }=\ln \left(\mathrm{FER}_{\mathrm{t}} / \mathrm{FER}_{\mathrm{t}-1}\right)
$$

Where FER is the Foreign Exchange Rate US \$/Rs 


\section{Inflation Rate}

The consumer price index (CPI) is used as a proxy for inflation. The CPI is a broad-based measure for calculating the average change in prices of goods and services during a specific period.

$$
\text { Inflation Rate }=\ln \left(\mathrm{CPI}_{\mathrm{t}} / \mathrm{CPI}_{\mathrm{t}-1}\right)
$$

\section{Trend in Log of Macroeconomic Series}

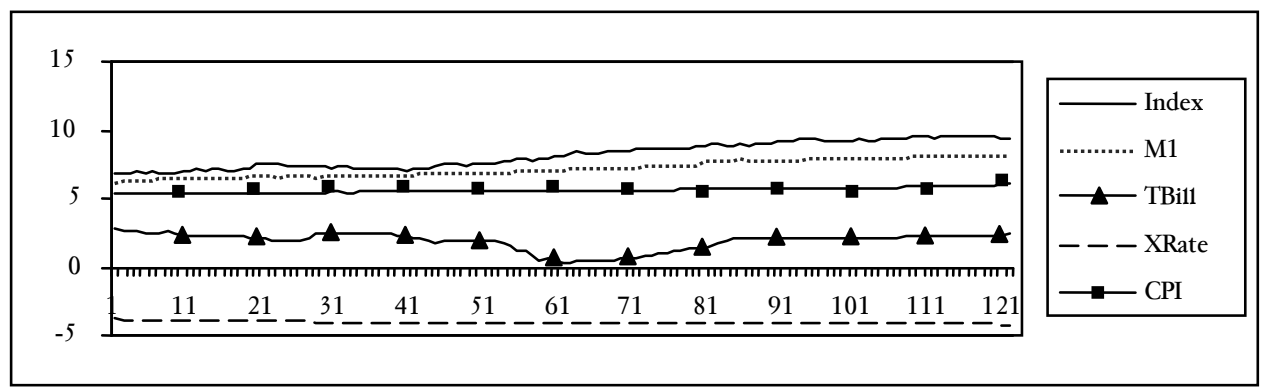

There are several techniques for testing the long-term dynamic interaction between prices in equity markets and macroeconomic variables. In this study, we emphasize testing the relationship between monetary variables and the Pakistani equity market, via:

- Descriptive statistics

- Correlation matrix

- Cointegration tests

- Granger causality test

- Impulse response analysis

- Variance decomposition analysis

The stationarity of data is tested using unit root tests. The null hypothesis of a unit root is tested using the Augmented Dickey-Fuller (ADF) Test and Phillips-Perron Test. The ADF test examines the presence of a unit root in an autoregressive mode1. $A$ basic autoregressive model is $Z_{t}=\alpha Z_{t-1}+$ $\boldsymbol{u}_{\mathrm{t}}$, where $Z_{\mathrm{t}}$ is the variable studied, $\mathrm{t}$ is the time period, $\alpha$ is a coefficient, and $u_{\mathrm{t}}$ is the disturbance term. The regression model can be written as $\Delta \mathrm{Z}_{\mathrm{t}}$ $=(\alpha-1) \mathrm{Z}_{\mathrm{t}-1}+u_{\mathrm{t}}=\delta \mathrm{Z}_{\mathrm{t}-1}+u_{\mathrm{t}}$, where $\Delta$ is the first difference operator. Here, testing for a unit root is equivalent to testing $\delta=0$.

The ADF tests assume that the error terms are statistically independent and have a constant variance. This assumption may not be true 
of all the data used, and so the Phillip-Perron test is used to relax the above assumptions and permit the error disturbances to be heterogeneously distributed. This can be represented mathematically by

$$
\mathrm{Z}_{\mathrm{t}}=\alpha_{\mathrm{o}}+\alpha_{1} \mathrm{Z}_{\mathrm{t}-1}+\alpha_{\mathrm{t}}\{\mathrm{t}-\mathrm{T} / 2\}+\mathrm{u}_{\mathrm{t}}
$$

Test statistics for the regression coefficients under the null hypothesis that the data are generated by $\mathrm{Z}_{\mathrm{t}}=\mathrm{Z}_{\mathrm{t}-1}+\mathrm{u}_{\mathrm{t}}$, where $\mathrm{E}\left(\mathrm{u}_{\mathrm{t}}\right)=0$.

If a time series is nonstationary but becomes stationary after differencing, then it is said to be integrated of the order one i.e. I (1). If two series are integrated of order one, there may exist a linear combination that is stationary without differencing. If such a linear combination exists then such streams of variables are called cointegrated.

Cointegration tests are divided into two broader categories: (i) residual-based tests, and (ii) maximum likelihood-based tests. Residual-based tests include the Engle-Granger (1987) test while maximum likelihood-based tests include the Johansen $(1988,1991)$ and Johansen-Juselius (1990) tests. During this study, we apply the Johansen and Juselius test to determine the presence of cointegrating vectors in a set of nonstationary time series data. The null hypothesis is that there is no cointegration among the series. The vector autoregressive (VAR) approach is employed to test multivariate cointegration. This assumes that all the variables in the model are endogenous. The Johansen and Juselius procedure is employed to test for a long-run relationship between the variables. Johansen and Juselius suggest two likelihood ratio tests for the determination of the number of cointegrated vectors. The maximal eigenvalue test evaluates the null hypothesis that there are at most $r$ cointegrating vectors against the alternative of $r+1$ cointegrating vectors. The maximum eigenvalue statistic is given by,

$$
\lambda_{\max }=-\mathrm{T} \ln \left(1-\lambda_{\mathrm{r}+1}\right)
$$

Where $\lambda \mathrm{r}+1, \ldots, \lambda \mathrm{n}$ are the $\mathrm{n}-\mathrm{r}$ smallest squared canonical correlations and $\mathrm{T}=$ the number of observations.

A trace statistic tests the null hypothesis of $\mathrm{r}$ cointegrating vectors against the alternative of $r$ or more cointegrating vectors. This statistic is given by

$$
\lambda_{\text {trace }}=-\mathrm{T} \Sigma \ln \left(1-\lambda_{\mathrm{i}}\right)
$$

In order to apply the Johansen procedure, lag length is selected on the basis of the Akaike Information Criterion (AIC). 
If cointegration is present in the long run, then the system of equations is restructured by inserting an error correction term to capture the short-run deviation of variables from their relevant equilibrium values. This is necessary as the impact of financial development is generally more apparent in the short run and disappears in the long run as the economy expands and matures. According to Granger (1988), the presence of cointegrating vectors indicates that Granger causality must exist in at least one direction. A variable Granger causes the other variable if it helps forecast its future values. In cointegrated series, variables may share common stochastic trends so that dependent variables in the VECM must be Granger-caused by the lagged values of the error correction terms. This is possible because error correction terms are functions of the lagged values of the level variables. Thus, evidence of cointegration between variables itself provides the basis for the construction of an error correction mode1 (ECM). The ECM permits the introduction of past disequilibrium as explanatory variables in the dynamic behavior of existing variables and thus facilitates in capturing both the short-run dynamics and long-run relationships between variables. The chronological Granger causality between the variables can be explored by applying a joint F-test to the coefficients of each explanatory variable in the VECM. The variance decomposition of equity returns is based on an analysis of responses of the variables to shocks. When there is a shock through the error term, we study the influence of this shock on other variables of the system and thus obtain information on the time horizon and percentage of the error variance. The $\mathrm{F}$ test is in fact a within-sample causality test and does not allow us to gauge the relative strength of the causality among variables beyond the sample period.

In order to examine out-of-sample causality, we use variance decomposition analysis which partitions the variance of the forecast error of a certain variable into proportions attributable to shocks to each variable in the system. Variance decomposition analysis presents a factual breakup of the change in the value of the variable in a particular period resulting from changes in the same variable in addition to other variables in preceding periods. The impulse response analysis investigates the influence of a random shock to a variable on other variables of interest. Impulse responses of returns in various markets to a shock in oil innovations are also examined. Impulse responses show the effect of shocks separately for different days whereas variance decomposition analysis exhibits the cumulative effect of shocks. 


\section{Empirical Results}

Table-1 exhibits descriptive statistics. The average monthly returns in percentage terms in the Karachi Stock Exchange are 2.2\% which is equivalent to an annualized return of $40.4 \%$. This is one of the highest returns offered by emerging equity markets. The maximum return in the Karachi stock market in 1 month is $24.11 \%$ whereas the maximum loss in one month is $27.8 \%$. The average money supply growth rate is $1.67 \%$ per month which is significantly high. Average inflation per month is $0.56 \%$ whereas $\mathrm{T}$ bill rates appear to change at a rate of $0.25 \%$ per month. The average decrease in the value of Pakistani currency is $0.35 \%$. Percentage changes in exchange rates range from a minimum of $-7.62 \%$ to a maximum value of $3.03 \%$. However, significant volatility is observed in equity returns and monetary variables, especially equity returns and interest rates.

Table-1: Descriptive Statistics

\begin{tabular}{lccccc}
\hline & Returns & $\begin{array}{c}\text { Money } \\
\text { growth rate }\end{array}$ & $\begin{array}{c}\text { Change in } \\
\text { T bill rate }\end{array}$ & $\begin{array}{c}\text { Change in } \\
\text { X rate }\end{array}$ & Inflation \\
\hline Mean & 0.0220 & 0.0167 & -0.0025 & -0.0035 & 0.0056 \\
Median & 0.0219 & 0.0091 & 0.0000 & -0.0006 & 0.0047 \\
Std Dev & 0.0912 & 0.0422 & 0.0985 & 0.0121 & 0.0070 \\
Skewness & -0.3055 & 0.0422 & 0.0121 & 0.0985 & 0.0070 \\
Minimum & -0.2780 & -0.0646 & -0.4242 & -0.0762 & -0.0088 \\
Maximum & 0.2411 & 0.3481 & 0.3200 & 0.0307 & 0.0303 \\
\hline
\end{tabular}

Weak correlation is observed between the equity return and monetary variables. The money growth rate is positively correlated with returns that are in line with results drawn by Maysami and Koh (2000). A possible reason for this is that an increase in money supply leads to an increase in liquidity that ultimately results in the upward movement of nominal equity prices. Interest rates are negatively correlated with equity returns, which is in line with economic rationale but this relationship is weak. An increase in interest rates leads to an increase in discount rates in the economy. Since the price of equity shares is theoretically equal to the present value of cash flows, higher discount rates lead to a reduction in prices. Similarly, the interest rate parity theory is also confirmed by our results as the interest rate is negatively correlated with exchange rates. However, the results indicate a weak correlation among variables as evident from Table- 2 . 
Table-2: Correlation Matrix

\begin{tabular}{lccccc}
\hline & Returns & $\begin{array}{c}\text { Money } \\
\text { growth rate }\end{array}$ & $\begin{array}{c}\text { Change in } \\
\text { T bill rate }\end{array}$ & $\begin{array}{c}\text { Change } \\
\text { in X rate }\end{array}$ & Inflation \\
\hline Returns & 1.0000 & & & & \\
Money growth rate & 0.0241 & 1.0000 & & & \\
Change in T bill rate & -0.1429 & -0.0198 & 1.0000 & & \\
Change in X rate & 0.1219 & 0.1455 & -0.1974 & 1.0000 & \\
Inflation & -0.1698 & -0.0145 & 0.2557 & -0.2029 & 1.0000 \\
\hline
\end{tabular}

Correlation analysis is a relatively weaker technique. The causal nexus among monetary variables has been investigated by employing multivariate cointegration analysis. Cointegration analysis tells us about the long-term relationship among equity returns and set of monetary variables. Cointegration tests involve two steps. In the first step, each time series is scrutinized to determine its order of integration. To meet this requirement, unit root tests designed by Dickey and Fuller (1979) and Phillips and Perron (1988) have been employed. In the second step, the time series is analyzed for cointegration by using the likelihood ratio test, which includes (i) trace statistics and (ii) maximum Eigen value statistics.

A financial time series is said to be integrated to order one i.e, I (1), if it becomes stationary after differencing once. If two series are integrated to order one and a linear combination of these is stationary without requiring differencing, then the data streams are cointegrated.

Our first step is to test the stationarity of the index series. For this purpose, the $\mathrm{ADF}$ test for unit roots has been used at level and first difference. Table-3 exhibits the results of the Dickey-Fuller (ADF test), which clearly show that the time series is not stationary at level but that the first differences of the logarithmic transformations of the series are stationary. Thus, the series is integrated to the order of one I (1). 
Table-3: Unit Root Analysis

\begin{tabular}{lcccc}
\hline & ADF- Level & ADF- Ist Diff & PP- Level & PP- Ist Diff \\
\hline Ln Index & -2.1686 & -12.015 & -2.0872 & -12.2821 \\
Ln Money supply & -1.8832 & -10.245 & -1.9545 & -10.2284 \\
Ln T bill rate & -1.6981 & -3.6063 & -1.3595 & -7.8162 \\
Ln X rate & -2.3659 & -6.6074 & -3.1003 & -6.4168 \\
Ln CPI & 2.9023 & -8.6160 & 2.6215 & -8.6190 \\
1\% Critic. Value & -4.0363 & -4.0363 & -4.0363 & -4.0363 \\
5\% Critic.Value & -3.4477 & -3.4477 & -3.4477 & -3.4477 \\
10\% Crit.1 Value & -3.1489 & -3.1489 & -3.1489 & -3.1489 \\
\hline
\end{tabular}

The Dickey-Fuller test requires that the error terms be statistically independent and data homoskedastic. However, in certain cases these assumptions may not be true for some data, and so we use another important technique, the Phillips-Perron test, to test the stationarity of the time series. Table-3 also displays the results of the Phillips-Perron test, which confirms the results of the ADF test. Thus, we can conclude that the series is I (1).

Having met these prerequisites, we can now perform cointegration analysis. The maximum likelihood-based Johansen $(1988,1991)$ test and Johansen-Juselius (1990) procedure is used to determine the presence of cointegrating equations in a set of nonstationary time series. A trace statistic has been used to test the null hypothesis of $r$ cointegrating vectors against the alternative of $r$ or more cointegrating vectors. Table-4 exhibits the results of the multivariate cointegration test for the entire sample period.

Table-4: Multivariate Cointegration Analysis Trace Statistic

\begin{tabular}{lcccc}
\hline $\begin{array}{l}\text { Hypothesized } \\
\text { No. of CE(s) }\end{array}$ & $\begin{array}{c}\text { Eigen } \\
\text { value }\end{array}$ & $\begin{array}{c}\text { Trace } \\
\text { Statistic }\end{array}$ & $\begin{array}{c}\text { Critical } \\
\text { Value0.05 }\end{array}$ & Prob. \\
\hline None ${ }^{*}$ & 0.21 & 71.27 & 69.82 & 0.04 \\
At most 1 & 0.17 & 44.20 & 47.86 & 0.11 \\
At most 2 & 0.09 & 22.60 & 29.80 & 0.27 \\
At most 3 & 0.07 & 12.17 & 15.49 & 0.15 \\
At most 4 & 0.03 & 3.52 & 3.84 & 0.06 \\
\hline
\end{tabular}

The trace test indicates one cointegrating equation at the $\alpha=0.05$. 
Table-5 fails to reject the null hypothesis of no cointegration between the equity indices and monetary variables for the period 6/1998 to 6/2008 in the Pakistani equity market. The trace test indicates the presence of one cointegrating equation at the 0.05 level. Therefore, the result provides evidence of a long-term relationship between monetary variables and equity prices. However, it must be noted here that the Johansen cointegration tests do not account for structural breaks in the data.

According to the representation theorem, if two variables are cointegrated then Granger-causality must exist in at least one direction. The results of Granger causality are reported in Table- 5 . Rejection of the null hypothesis at $5 \%$ indicates that there exists unidirectional Granger causality between the money growth rate and equity returns at the $5 \%$ level. Similarly, unidirectional Granger causality also exists between the interest rate, inflation, exchange rate and equity returns. This indicates that monetary variables are Granger-causing equity returns. Treasury bill rates are also Granger-causing exchange rates. These results are consistent with Nishat (2001) who indicates that inflation and equity returns are negatively related to each other. 
Table-5: Granger Causality Test

\begin{tabular}{lccc}
\hline Null Hypothesis & Obs & F-Statistic & Probability \\
\hline M1 Growth does not Granger Cause Returns & 117 & 2.865 & 0.040 \\
Returns does not Granger Cause M1 Growth & & 0.566 & 0.639 \\
T bill rate does not Granger Cause Returns & 117 & 3.511 & 0.018 \\
Returns does not Granger Cause T bill rate & & 0.906 & 0.441 \\
Change in X rate does not Granger Cause Returns & 117 & 6.191 & 0.001 \\
Returns does not Granger Cause Change in X rate & & 0.099 & 0.960 \\
CPI does not Granger Cause Returns & 117 & 2.980 & 0.035 \\
Returns does not Granger Cause CPI & & 0.395 & 0.757 \\
T bill rate does not Granger Cause M1 Growth & 117 & 3.546 & 0.017 \\
M1 Growth does not Granger Cause T bill rate & & 1.938 & 0.128 \\
Change in X rate does not Granger Cause M1 & 117 & 0.481 & 0.696 \\
M1 does not Granger Cause Change in X rate & & 0.146 & 0.932 \\
CPI does not Granger Cause M1 Growth & 117 & 2.078 & 0.107 \\
M1 Growth does not Granger Cause CPI & & 0.376 & 0.770 \\
Change in X rate does not Granger Cause T bill rate & 117 & 1.113 & 0.347 \\
T bill rate does not Granger Cause Change in X rate & & 3.087 & 0.030 \\
CPI does not Granger Cause T bill rate & 117 & 0.924 & 0.432 \\
T bill rate does not Granger Cause CPI & & 1.180 & 0.321 \\
CPI does not Granger Cause Change in X rate & 117 & 1.203 & 0.312 \\
Change in X rate does not Granger Cause CPI & & 1.668 & 0.178 \\
\hline
\end{tabular}

Since a long-run association has been observed between equity prices and monetary variables, we can explore the possibility of a short-run relationship by using an ECM framework. The results of the ECM report indicate that the error term is significant at $\alpha=0.05$ and $33 \%$ of disequilibrium is adjusted within a lag of one period.

ecm $=1 n$ index $-1.3963 * \mathrm{M} 1+0.19526 * \operatorname{LnTBILL}-1.3288^{*} \operatorname{LnXRATE}-$ $0.70738 * \operatorname{LnCPI}$

It is worth mentioning that the coefficients of the money supply, T-bill rate and exchange rate are significant at $\alpha=0.05$. 
The responses of equity returns have also been examined by using impulse response analysis (IRF) in the VAR system and results are shown in Figure-1. Impulse response functions capture the effect innovations in money growth rate, T-bill rates, exchange rate and inflation on equity returns in the Karachi stock market. Figure-1 shows the impulse response of equity returns from a one standard deviation shock to monetary variables. The statistical significance of the impulse response function has been examined at $95 \%$ confidence bounds. These figures confirm that a one standard deviation change in money supply leads to an increase in equity prices due to an increase in liquidity; this result is consistent with Maysami and Koh (2000). Similarly, a one standard deviation change in the T-bill rate leads to a reduction in the price of equity due to increased discount rates. No statistically significant impact has been observed with reference to a variation in exchange rates. This is reasonable because Pakistan has had a managed floating rate system and, during the last five years, exchange rates have been managed within a small range by the State Bank of Pakistan through open market operations. These results are in conformity with earlier work.

\section{Fig.-1: Impulse Response Analysis}

\section{Response to Cholesky One S.D. Innovations}
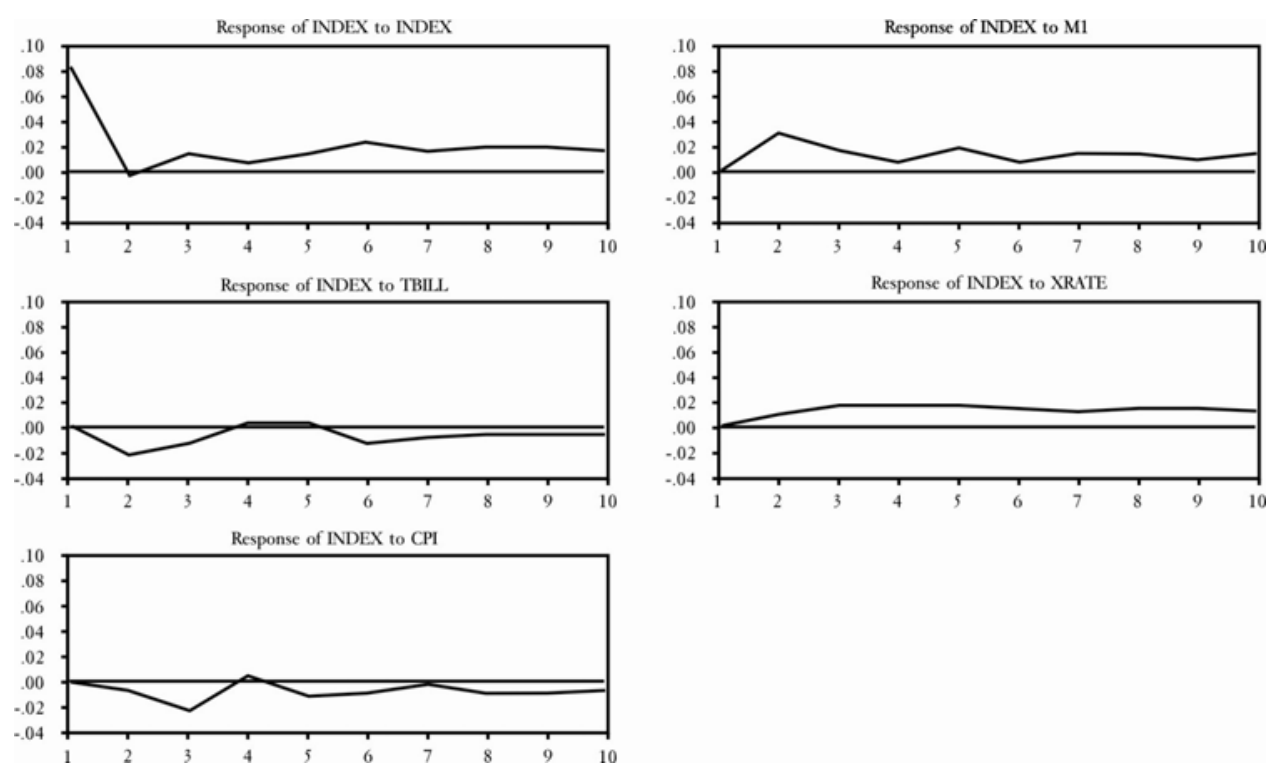

Impulse response functions display the response of an endogenous variable over time to a given innovation. On the other hand, variance decomposition analysis expresses the contributions of each source of innovation to the forecast error variance for each variable. Thus, we have 
conducted a variance decomposition analysis to measure the degree to which shocks to the equity market are explained by money supply, T-bill rates, exchange rates and inflation. This also supports the pattern of linkages between monetary variables and equity markets and enhances our insights into the reaction of markets to system-wide shocks. It also helps identify the pattern of response transmission over time. Table 6 exhibits the decomposition of forecast error variance for the equity market that is explained by monetary variables.

Table-6: Variance Decomposition Analysis

\begin{tabular}{lcccccc}
\hline Period & \multirow{2}{*}{ SE } & \multirow{2}{*}{ Returns } & M1 & \multicolumn{2}{c}{ Change in } & \multicolumn{2}{c}{ Change } & Change in \\
Trowth & T bills rate & in X rate & CPI \\
\hline 1 & 0.0838 & 100.0000 & 0.0000 & 0.0000 & 0.0000 & 0.0000 \\
2 & 0.0927 & 81.8340 & 10.6955 & 6.2005 & 0.9531 & 0.3169 \\
3 & 0.1005 & 71.9706 & 12.1346 & 7.2983 & 3.7298 & 4.8667 \\
4 & 0.1026 & 69.7728 & 12.2185 & 7.0533 & 6.0189 & 4.9365 \\
5 & 0.1078 & 64.9402 & 14.6710 & 6.4407 & 8.2748 & 5.6734 \\
6 & 0.1127 & 63.7044 & 13.8983 & 7.2692 & 9.4382 & 5.6900 \\
7 & 0.1159 & 62.3909 & 14.9289 & 7.3497 & 9.9227 & 5.4079 \\
8 & 0.1195 & 61.0919 & 15.4836 & 7.1243 & 10.7386 & 5.5616 \\
9 & 0.1228 & 60.2977 & 15.4341 & 6.9971 & 11.6140 & 5.6571 \\
10 & 0.1259 & 59.0425 & 16.1902 & 6.9894 & 12.2330 & 5.5450 \\
\hline
\end{tabular}

Variance decomposition analysis suggests that the money growth rate, change in T-bill rate and change in exchange rate are considerable sources of volatility in equity returns. The contribution of an exchange rate shock to equity returns ranges from 6.2 to $7.3 \%$. Similarly, the contribution of changes in T-bill rates and inflation to the equity market is also significantly high, ranging from 4 to $6 \%$. The money growth rate also contributed to equity market volatility during 1998-2008.

\section{Conclusion}

This paper examines the lead lag relationship among stock prices and four important monetary variables which include money supply, T-bill rates, exchange rates, and inflation for the period 6/1998 to 6/2008 by using multivariate cointegration analysis and the Granger causality test. The results provide evidence on information transmission in equity markets and explain 
the impact of changes in monetary variables on the stock market. Multivariate regression analysis provides evidence of one cointegration vector, which is an indicator of a long-term relationship among the variables concerned.

The Granger causality test indicates that the money growth rate Granger-causes returns. This appears logical as an increase in money supply leads to increased inflation, which translates into discount rates and ultimately results in reduction of prices. Similarly, the T-bill rate and inflation Granger-cause equity returns. These results are consistent with Nishat (2001) who indicates that inflation and equity returns are negatively related. The impulse response analysis shows that a one standard deviation change in money supply leads to an increase in equity prices due to an increase in liquidity; this is consistent with Maysami and Koh (2000).

Similarly, a one standard deviation change in the T-bill rate leads to a reduction in the prices of equity due to increased discount rates. A statistically significant impact has been observed with reference to variations in exchange rates. In order to take an overall view of the volatility of returns, we performed a variance decomposition analysis which revealed that the money growth rate, change in T-bill rate and change in exchange rate are considerable sources of volatility in equity returns. The contribution of an exchange rate shock to equity returns ranges from 3 to $14 \%$. Similarly, the contribution of changes in T-bill rates to the equity market is also significant. The money growth rate also contributed to equity market volatility during 1998-2008. Similarly, the significant impact of inflation on equity prices is captured in our findings.

We can conclude that monetary variables have a long-run as well as short-run relationship with equity returns. The identification of the impact of monetary variables on stock market behavior facilitates investors in making effective investment decisions as by estimating expected trends in exchange rates, interest rate, and money supply, investors can estimate the future direction of equity prices and thus allocate their resources more efficiently. Architects of monetary policy should keep in mind the impact of changes in interest rates on the capital market in the form of a reduction of prices. The central bank should consider the impact of money supply on capital markets. Under the efficient market hypothesis, capital markets respond to the arrival of new information, implying that macroeconomic policies should be designed to provide stability to the capital market. 


\section{References}

Abdalla, I. S. A. Murinde, V., 1997, "Exchange Rate and Stock Price Interactions in Emerging Financial Markets: Evidence on India, Korea, Pakistan, and Philippines," Applied Financial Economics, Vo1. $7: 25-35$.

Bahmani-Oskooee, M. Sohrabian, A., 1992, "Stock Prices and the Effective Exchange Rate of the Dollar," Applied Economics, Vol. 24 : 459464.

Beenstock, M. and Chan, K., 1988, "Economic Forces in the London Stock Market," Oxford Bulletin of Economics and Statistics, Vo1. 50 (1) : 27-39.

Burmeister, E. and K.D. Wall, 1986, "The Arbitrage Pricing Theory and Macroeconomic Factor Measures," The Financial Review, Vol. 21 (1) $: 1-20$.

Burmeister, E. and M.B. McElroy, 1988, "Joint Estimation of Factor Sensitivities and Risk Premia for the Arbitrage Pricing Theory," The Journal of Finance, Vo1. 43 (3) : 721-735.

Chan, K.C., N.F. Chen and D.A. Hsieh, 1985, "An Exploratory Investigation of the Firm Size Effect,” Journal of Financial Economics, Vo1. 14 : 451-471.

Chang, E.C. and J.M. Pinegar, 1990, "Stock Market Seasonals and Prespecified Multifactor Pricing Relations," Journal Of Financial and Quantitative Analysis, Vol. 25 (4) : 517-533.

Chen, N. F., Roll, R. \& Ross, S.A., 1986. "Economic Forces and the Stock Market," Journal of Business, Vo1. 59 : 383-403.

DeFina, R.H., 1991, “Does Inflation Depress the Stock Market?" Business Review, Federal Reserve Bank of Philadelphia : 3-12.

Dickey, D. A. and Fuller, W. A., 1981, "Likelihood Ratio Statistics for Autoregressive Time Series with a Unit Root," Econometrica, Vol. 49 (4): 1057-72. 
Engle, R.F. and Granger, C.W.J., 1987, "Cointegration and Error Correction: Representation, Estimation and Testing," Econometrica, Vo1. 5 5: 251-276.

Fama E. F. and Schwert, W.G., 1977, “Asset Returns and Inflation,” Journal of Financial Economics, Vo1. 5 : 115-146.

Granger, C.W.J., 1988, "Some Recent Developments in a Concept of Causality,” Journal of Econometrics, Vo1. 39 (1/2) : 199-211.

Hamao, Y., 1988, "An Empirical Investigation of the Arbitrage Pricing Theory," Japan And the World Economy, Vol. 1 : 45-61.

Hamburger, M. J. and Kochin, L. A., 1972, "Money and Stock Prices: The Channels of Influence,” Journal of Finance, Vol. 27 (2) : 231-249.

Hassan, A. H., 2003, "Financial Integration of Stock Markets in the Gulf: A Multivariate Cointegration Analysis," International Journal of Business, Vol. 8 (3).

Humpe, A., and Macmillan, P., 2007, "Can Macroeconomic Variables Explain Long Term Stock Market Movements? A Comparison of the US and Japan," CDMA Working Paper No. 07/20.

Hussain. F., and Mahmood. T., 2001, "The Stock Market and the Economy of Pakistan," The Pakistan Development Review, Vol. 40 (2) : 107114.

Jaffe, J. \& Mandelkar, G., 1976, "The Fisher Effect for Risky Assets: An Empirical Investigation,” Journal of Finance, Vo1. 31 : 447-456.

Johansen, S., 1988, "Statistical Analysis of Cointegrating Vectors," Journal of Economic Dynamic and Control, Vo1. 12 : 231-254.

Johansen, S., 1991, "Estimation and Hypothesis Testing of Cointegrating Vectors in Gaussian Vector Autoregressive Models," Econometrica, Vol. $59: 1551-1580$.

Johansen, S., 1992, "Determination of Cointegration Rank in the Presence of a Linear Trend," Oxford Bulletin of Economics and Statistics, Vol. 54 (3) : 383-397. 
Johansen, S., and K. Juselius, 1990, "Maximum Likelihood Estimation and Inference on Cointegration with Application to the Demand for Money," Oxford Bulletin of Economics and Statistics, Vo1. 52 : 169209.

Jones, C. M. and Kaul, G., 1996, "Oil and the Stock Market," Journal of Finance, Vo1. 51 : 463-491.

Kraft, J. and A. Kraft, 1977, "Determinants of Common Stock Prices: A Time Series Analysis,” Journal of Finance, Vo1. 32 (2) : 417-425.

Kryzanowski,L. and H. Zang, 1992, "Economic Forces and Seasonality in Security Returns," Review of Quantitative Finance and Accounting, Vol.2 : 227-244.

Ma, C. K. Kao, G. W., 1990, "On Exchange Rate Changes and Stock Price Reactions,” Journal of Business Finance and Accounting, Vol. 17 : 441-449.

Maysami, R. C. and Koh, T. S., 2000, "A Vector Error Correction Model of the Singapore Stock Market," International Review of Economics and Finance, Vo1. 9 : 79-96.

Mishra A.K., 2004, "Stock Market and Foreign Exchange Market in India: Are They Related?” South Asia Economic Journal, Vo1. 5 : 209-232.

Muhammad, N. Rasheed, A., 2003, "Stock Prices and Exchange Rates: Are they Related? Evidence from South Asian Countries," Paper presented at the 18th Annual General Meeting and Conference of the Pakistan Society of Development Economists, January 2003.

Mukherjee, $\mathrm{T}$ and A. Naka, 1995, "Dynamic Relations between Macroeconomic Variables and the Japanese Stock Market: An Application of a Vector Error Correction Mode1," Journal of Financial Research, Vo1. 18 : 223-37.

Nelson, C. R., 1976, "Inflation and Rates of Return on Common Stocks," Journal of Finance, Vo1. 31 (2) : 471-483.

Nishat M. and Rozina. S., 2004, "Macroeconomic Factors and Pakistani Equity Market," The Pakistan Development Review, Vol. 43 (4) : 619-637. 
Nozar, H. and Taylor, P., 1988, "Stock Prices, Money Supply and Interest Rates: The Question of Causality," Applied Economics, Vol. 20 : 103-161.

Osterwald-Lenum, M., 1992, “A Note with Quintiles of the Asymptotic Distribution of the Maximum Likelihood Cointegration Rank Test Statistics," Oxford Bulletin of Economics and Statistics, Vo1. 50 : 361-377.

Phillips, P. and Perron, P., 1988, "Testing for a Unit Root in Time Series Regression," Biometrica, 75: 335-46.

Phylaktis, K. Ravazzolo, F., 2000, "Stock Prices and Exchange Rate Dynamics," Paper presented at the EFMA 2000 Meeting in Athens, May 2000.

Rahman, S., T.D. Coggin and C.F. Lee, 1998, "Some Tests of the RiskReturn Relationship Using Alternative Pricing Models and Observed Expected Returns," Review of Finance and Accounting, Vo1. 11 : 6991.

Roll, Richard and Stephen A. Ross, 1980, "An Empirical Investigation of the Arbitrage Pricing Theory,” Journal of Finance, Vo1. 35 : 1073-1103.

Ross, S. A., 1976, "The Arbitrage Theory of Capital Asset Pricing," Journal of Economic Theory, Vol. $13: 341-360$.

Solnik, B., 1987, "Using Financial Prices to Test Exchange Rate Models: A Note,” Journal of Finance, Vo1. 42 : 141-149.

Stavárek, D., 2004, "Stock Prices and Exchange Rates in the EU and the USA: Evidence of their Mutual Interactions," Czech Journal of Economics and Finance, Vol. 55.

Yu, Q., 1997, "Stock Prices and Exchange Rates: Experience in Leading East Asian Financial Centres: Tokyo, Hong Kong and Singapore," Singapore Economic Review, Vo1. 41 : 47-56.

Zhou, G., 1999, "Security Factors as Linear Combinations of Economic Variables,” Journal of Financial Markets, Vo1. 2 : 403-432. 